\title{
Assessment of Health Risks Related to the Consumption of Minced Meat Sandwich
}

\author{
Alain B. Vouidibio Mbozo (Corresponding author) \\ Cellular and Molecular Biology Laboratory, Faculty of Sciences and Techniques, \\ Marien Ngouabi University, PO Box 69 Brazzaville, Republic of the Congo \\ Multidisciplinary Food and Nutrition Research Team (EPRAN) \\ PO Box 389 Brazzaville, Republic of the Congo \\ E-mail: vouidibio333@gmail.com
}

\section{Christian A. Kayath}

Cellular and Molecular Biology Laboratory, Faculty of Sciences and Techniques, Marien Ngouabi University, PO Box 69 Brazzaville, Republic of the Congo National Institute for Research in Exact and Natural Sciences (IRSEN) Avenue de l'Auberge Gascogne, PO Box 2400 Brazzaville, Republic of the Congo E-mail: chriskayath@yahoo.fr

\section{Saturnin N. Mokémiabéka}

Cellular and Molecular Biology Laboratory, Faculty of Sciences and Techniques, Marien Ngouabi University, PO Box 69 Brazzaville, Republic of the Congo Multidisciplinary Food and Nutrition Research Team (EPRAN) PO Box 389 Brazzaville, Republic of the Congo E-mail: elmok2003@yahoo.fr

\section{Etienne Nguimbi}

Cellular and Molecular Biology Laboratory, Faculty of Sciences and Techniques, Marien Ngouabi University, PO Box 69 Brazzaville, Republic of the Congo National Institute for Research in Exact and Natural Sciences (IRSEN) 
Avenue de l'Auberge Gascoigne, PO Box 2400 Brazzaville, Republic of the Congo

E-mail: Etienne.ng1612@gmail.com

\author{
Received: April 13, 2020 Accepted: May 25, 2020 Published: May 30, 2020 \\ doi:10.5296/jfs.v9i1.17106 URL: https://doi.org/10.5296/jfs.v9i1.17106
}

\begin{abstract}
The objective of this work was to assess the health risks associated with the consumption of minced meat sandwiches, sold in the informal sector in Brazzaville in the Republic of Congo. A survey on the application of hygiene rules was conducted in parallel with a bacteriological analysis of cooked minced meat. The enterobacteria isolated from this food were identified and antibiotic resistance testing was performed. The investigation revealed shortcomings in respect of basic hygiene rules, and $56 \%$ of the sandwiches analyzed were of bacteriological quality unsatisfactory. The non-compliance of the sandwiches was caused mainly by the presence total aerobic mesophilic flora $(71.43 \%)$ and total coliforms $(57.14 \%)$. In contrast, not all samples were contaminated with anaerobes sulfito-reducting bacteria and Salmonella. Five species of Enterobacteriaceae were identified: Escherichia coli (35.30\%), Proteus vulgaris (11.76\%), Klebsiella oxytoca (11.76\%), Citrobacter spp. (23.53\%) and Enterobacter cloacae $(17.65 \%)$. Of these, $42.65 \%$ were resistant to $75 \%$ of antibiotics tested: Cefalexin (17.24\%), Ceftriaxone (48.28\%) and Norfloxacin (34.48\%). In contrast, all strains were sensitive to Nitrofurantoin. Minced meat sandwiches sold in informal sector in Brazzaville can be source of enteropathogens, susceptible to expose consumers to foods poisonings.
\end{abstract}

Keywords: Pathogenic bacteria, Food contamination, Health risks, Minced meat, Brazzaville

\title{
1. Introduction
}

The minced meat sandwich is a ready-to-eat food consisting of cooked minced meat sandwiched in bread. It is widely consumed in Brazzaville. Meat is considered as food of choice because of its nutritional value. However, for the same reason, it is a favorable environment for bacterial proliferation (Phillips et al., 2001). Bacterial activities have a great influence on the organoleptic and hygienic quality of food products (Guiraud, 2003). Indeed, they can cause changes in taste, color, smell and produce metabolites harmful to the health of consumers. In the case of meat, the harmful effects of the bacterial flora are favored by the chopping operation it undergoes (Phillips et al., 2001); the minced meat is so a fragile food which must be strictly monitored because of the danger due to these alterations and the presence of potentially pathogenic agents.

Meat foods ready to eat have been repeatedly criminalized in collective food poisoning throughout the world (Cohen \& Karib, 2006); sandwiches and salads have been implicated in food borne epidemics (Christison et al., 2008). These foods are often prepared by hand; this direct contact can lead to an increased incidence of contamination by pathogens such as 


\section{Macrothink}

Staphylococcus aureus (Kotzekidou, 2013). Handling, storage conditions, and food exposure at the time of sale are factors that influence the bacteriological burden of ready-to-eat foods.

In the Republic of Congo, minced meat sandwich is generally sold in the informal sector at the level of mini-feeds. In these outlets, often poorly designed (one room with only one door serving as an exit and entrance), the preparation and sale of sandwiches are done in parallel with the sale of other merchandise merchandise in the same premises. This situation does not guarantee the bacteriological quality of this food, which represents a risk to the health of consumers. In addition, despite the increased incidence of food-borne illnesses, minced meat used in these fast food establishments has never been microbiologically investigated.

This work consists of an evaluation of compliance with hygiene rules at the point of sale, the bacteriological quality of minced meat and the antimicrobial resistance of enterobacteria, possibly present in this foodstuff.

\section{Material and Methods}

\subsection{Investigation}

The survey was conducted in the form of an interview and observation of staff at work. It involved seven sellers at five points of sale (A, B, C, D and E respectively), three of which were at point of sale B. Sites A, B and C are located in district 2 Bacongo, while sites D and E are located in district 1 Makélékélé. The main selection criteria were: own the store and be willing. The choice of points of sale was made taking into account the size of the influx of customers. The survey mainly consisted in evaluating the application of good hygiene, preparation and sales practices, but also the profile of the sellers.

\subsection{Sampling}

A total of twenty-five (25) ground meat sandwiches were collected, at the rate of one (1) sandwich per visit and five sandwiches per points of sale (Table 1). The samples were packaged in sterile plastic bags and transported immediately to at laboratory in cooler.

Table 1. Provenances and codification of samples

\begin{tabular}{llll}
\hline Borough & Point of sale & Number sellers & Number samples \\
\hline Bacongo & A & 03 & $5: \mathrm{B}_{1}, \mathrm{~B}_{2}, \mathrm{~B}_{3}, \mathrm{~B}_{4}$ et $\mathrm{B}_{5}$ \\
Bacongo & B & 01 & $5: \mathrm{S}_{1}, \mathrm{~S}_{2}, \mathrm{~S}_{3}, \mathrm{~S}_{4}$ et $\mathrm{S}_{5}$ \\
Bacongo & C & 01 & $5: \mathrm{C}_{1}, \mathrm{C}_{2}, \mathrm{C}_{3}, \mathrm{C}_{4}$ et $\mathrm{C}_{5}$ \\
Bacongo & $\mathrm{D}$ & 01 & $5: \mathrm{L}_{1}, \mathrm{~L}_{2}, \mathrm{~L}_{3}, \mathrm{~L}_{4}$ et $\mathrm{L}_{5}$ \\
Makélékélé & E & 01 & $5: \mathrm{F}_{1}, \mathrm{~F}_{2}, \mathrm{~F}_{3}, \mathrm{~F}_{4}$ et $\mathrm{F}_{5}$ \\
& & & 25 \\
Total & & 07 & \\
\hline
\end{tabular}

\subsection{Bacteriological Analysis}

Bacteriologicals analyses were performed according to the standards techniques reported by Joffin and Joffin (2003). They included enumerations of the total aerobic mesophilic flora at 
$30^{\circ} \mathrm{C}$ (FMAT), total coliform (CT), fecal coliform (CF), anaerobes sulfito-reducting (ASR) and Staphylococcus suspected pathogens (SSP) and a search for Salmonella.

\subsubsection{Sample Processing}

About $25 \mathrm{~g}$ of minced meat was homogenized in $225 \mathrm{~mL}$ peptone water and mixed properly. The homogenate was then filtered using a filter paper. The filtrate obtained constitutes the prime solution (dilution $10^{-1}$ ) from where decimal dilutions have been made.

\subsubsection{Enumeration and Research of Different Flora}

- Enumeration of the FMAT. One (1) $\mathrm{ml}$ of the $10^{-11}$ and $10^{-12}$ decimal dilutions were respectively inoculated deep down in PCA supercooling agar. After solidification, $4 \mathrm{~mL}$ of agar was surface-cast to obtain a double layer. Incubation was performed at $30^{\circ} \mathrm{C}$ for $72 \mathrm{~h}$ (AFNOR, 1999).

- Enumeration of coliforms. Total and fecal coliform enumeration was performed by inoculating $1 \mathrm{ml}\left(10^{-8}\right.$ and $10^{-9}$ dilutions $)$ on deoxycholate agar. Incubation was for 24 hours at $37^{\circ} \mathrm{C}$ and $44^{\circ} \mathrm{C}$, respectively (ISO7251, 2005).

- Enumeration and search for SSP. It was carried out by spreading $0.1 \mathrm{ml}\left(10^{-4}\right.$ and $10^{-5}$ dilutions) on the surface of Baird Parker agar. Incubation was performed at $37^{\circ} \mathrm{C}$ for $48 \mathrm{~h}$ (ISO 6888-1, 1999). The coagulase test was performed by mixing a suspicious colony in 5 $\mathrm{mL}$ of heart-brain broth, followed by incubation at $37^{\circ} \mathrm{C}$ for 24 hours. A volume of $0.3 \mathrm{~mL}$ of rabbit plasma was then mixed with $0.1 \mathrm{~mL}$ of the culture obtained and then incubated at $37^{\circ} \mathrm{C}$ for 24 hours. Coagulation of more than half the volume means a positive result.

- Enumeration and SRA. $1 \mathrm{ml}$ of the stock solution was seeded into Tryptone Sulfite Neomycin (TSN) agar. Incubation was done for $24 \mathrm{~h}$ at $37^{\circ} \mathrm{C}$ (ISO7937: 2005).

- Salmonella search

Pre-enrichment was performed by incubating the stock solution at $37^{\circ} \mathrm{C}$ for $18 \mathrm{~h}$. Then $0.1 \mathrm{ml}$ of the pre-enriched solution was transferred to $10 \mathrm{ml}$ of selenite cystine broth contained in a test tube. After homogenization, the tube is incubated at $37^{\circ} \mathrm{C}$ for $24 \mathrm{~h}$. Isolation was achieved by spreading approximately $50 \mu \mathrm{l}$ of enriched medium on the surface of Salmonella-Shigella agar before being incubated at $37^{\circ} \mathrm{C}$ for $24 \mathrm{~h}$. Finally, the identification was done using the gallery API $20 \mathrm{E}$ as described by the manufacturer.

\subsection{Results Interpretation}

Only the Petri dishes containing between 15 and 300 colonies were considered. The results have been interpreted on the basis of criteria defined by the ministerial decree of December 21, 1979 revised on April 27, 2006 (French Republic, 2006).

\subsection{Identification of Isolated Enterobacteriaceae}

After enumeration, twenty colonies were randomly selected for biochemical analyzes. The isolates were purified by repeated subculturing, then store at $4{ }^{\circ} \mathrm{C}$ on sloping agar. The following characters were determined: spore production, Gram type, motility and production of catalase; the suspected strains were identified using the integrated Enterobatteri system (Ref. 71714) as described by the manufacturer.

\subsection{Antibiotic Resistance Testing}

About $5 \mathrm{ml}$ of nutrient broth was inoculated with a colony of the test strain and incubated at 


\section{Macrothink}

$37{ }^{\circ} \mathrm{C}$ overnight at an inoculum density equivalent to a $0.5 \mathrm{McFarland}$ turbidity standard. A sterile cotton swab was moistened with each isolate and used to swab duplicate Muller-Hinton agar plates. Then, the plates were left to dry for about $5 \mathrm{~min}$ before placing the antibiotics discs on each of the plates as described by Bauer, (1996). Antibiotic discs and concentrations used were: Ceftriaxone $(\mathrm{CRO}, 30 \mu \mathrm{g})$, Norfloxacin (NOR, 10 $\mu \mathrm{g}$ ), Cefalexin $(\mathrm{CN}, 30 \mu \mathrm{g})$ and Nitrofurantoin (FT, 300 $\mathrm{g}$ ). The diameter of the inhibition zone has been measured in millimeters. The different isolates have been described as susceptible/resistant based on the recommendations of National Committee for Clinical Laboratory Standards Institute (CLSI, 2013).

\section{Results and Discussion}

\subsection{Investigation}

All sales people are of Senegalese based in Brazzaville, whose age is between 30 and 45 . None of the vendors have completed high school or been trained in catering. The various sales outlets are not compartmentalized, the sellers do not wear an apron or headdress and the non-respect of the principle of walking forward and the presence of a pet have been noted. The meat used is bovine in nature. Vendors get it at cold rooms in the market. They carry out with bare hands the preparation and sale of sandwiches. The preparation is similar in the different points sale visited (Figure.1), and the sale is made in parallel with that of the other merchandise of the point of sale. The sandwich is wrapped with newspaper to be served to the customer.

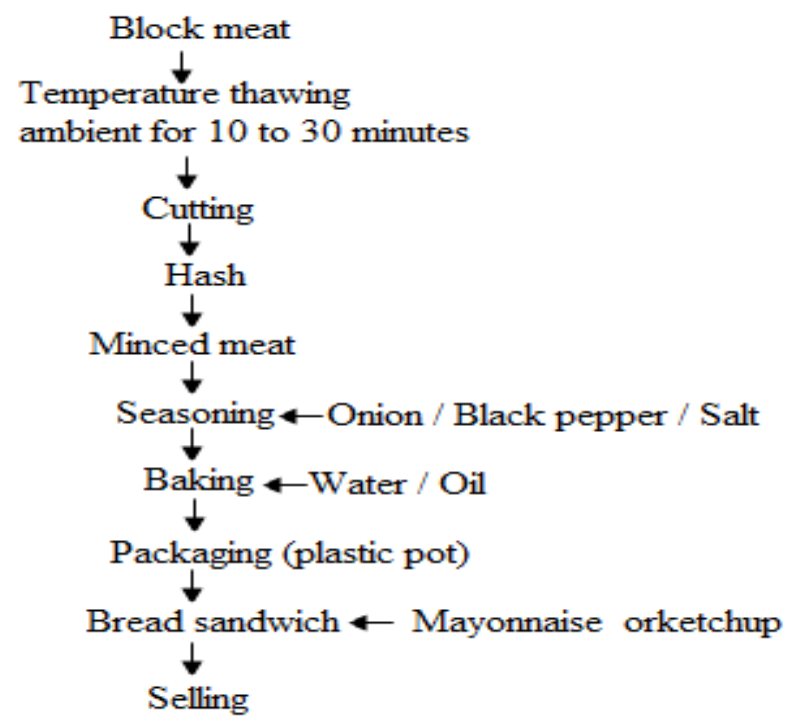

Figure 1. Diagram of preparation of minced meat sandwich

These observations highlight a lack of knowledge or negligence of basic hygiene rules by sellers. This fact has been reported for a large number of ready-to-eat foods in the informal sector in Africa, as, Kilishi, sausages, KobaRavina and dry meat (Barro et al., 2002; Mensah et al., 2002; Ranaivoarimanana, 2006; Barro et al., 2007; Badibanga, 2008; Ogunsola \& Omojola, 2008; Anin et al., 2016). 


\subsection{Bacteriological Analysis}

Results of the various analyses are presented in Table 2. The mini-feeds A, C, D and E had at least $60 \%$ non-compliant samples, compared to $20 \%$ for the B outlet. The percentages of satisfactory quality samples, acceptable and unsatisfactory, were $36 \%, 8 \%$ and $56 \%$ respectively. The total flora is responsible for the non-compliance of the largest number $(71.43 \%)$ of samples (Figure 2). In contrast, no sulfite-reducing anaerobic bacteria, or salmonella were found in our samples.

Table 2. Bacterial load and microbiological quality of samples

\begin{tabular}{|c|c|c|c|c|c|c|c|}
\hline \multirow{3}{*}{ Samples } & FMAT & $\mathrm{CT}$ & $\mathrm{CF}$ & SSP & ASR & Salmonella & \multirow{3}{*}{ Results } \\
\hline & \multicolumn{6}{|c|}{ Norms (ufg/g) } & \\
\hline & $3.10^{5}$ & $10^{3}$ & 10 & $10^{2}$ & 30 & $\mathrm{Abs}$ in $25 \mathrm{~g}$ & \\
\hline
\end{tabular}

Site A

$\begin{array}{llllllll}\text { B1 } & 7.3 .10^{5} & 8.10^{2} & 5 & 1.3 .10^{1} & 00 & \text { Abs } & \text { S } \\ \text { B2 } & 1.2 .10^{6} & 10^{3} & 18 & 5.10^{1} & 00 & \text { Abs } & \text { A } \\ \text { B3 } & 10^{6} & 3.4 .10^{3} & 12 & 4.6 .10^{1} & 00 & \text { Abs } & \text { NS } \\ \text { B4 } & 2.2 .10^{6} & 1.2 .10^{3} & 240 & 2.1 .10^{1} & 00 & \text { Abs } & \text { NS } \\ \text { B5 } & 1.2 .10^{6} & 1.53 .10^{4} & 3 & 4.1 .10^{1} & 00 & \text { Abs } & \text { NS }\end{array}$

Site B

$\begin{array}{llllllll}\text { S1 } & 1.7 .10^{5} & 1.7 .10^{3} & 23 & 2.3 .10^{1} & 00 & \text { Abs } & \text { S } \\ \text { S2 } & 3.5 .10^{5} & 2.1 .10^{3} & 25 & 1.1 .10^{1} & 00 & \text { Abs } & \text { S } \\ \text { S3 } & 1.2 .10^{6} & 10^{3} & 7 & 3.6 .10^{2} & 00 & \text { Abs } & \text { NS } \\ \text { S4 } & 2.9 .10^{5} & 9.8 .10^{2} & 16 & 7.10^{1} & 00 & \text { Abs } & \text { S } \\ \text { S5 } & 3.6 .10^{5} & 2.10^{3} & 17 & 2.6 .10^{1} & 00 & \text { Abs } & \text { S }\end{array}$

Site C

$\begin{array}{llllllll}\text { C1 } & 1.29 .10^{6} & 2.10^{2} & 27 & 10^{1} & 00 & \text { Abs } & \text { A } \\ \text { C2 } & 6.6 .10^{5} & 3.5 .10^{3} & 220 & 1.4 .10^{1} & 00 & \text { Abs } & \text { NS } \\ \text { C3 } & 5.3 .10^{5} & 3.1 .10^{3} & 130 & 1.2 .10^{1} & 00 & \text { Abs } & \text { NS } \\ \text { C4 } & 1.35 .10^{6} & 3.10^{2} & 6 & 5.2 .10^{2} & 00 & \text { Abs } & \text { NS } \\ \text { C5 } & 4.2 .10^{5} & 1.3 .10^{3} & 10 & 2.1 .10^{1} & 00 & \text { Abs } & \text { S }\end{array}$

Site D

$\begin{array}{llllllll}\text { L1 } & 7.5 .10^{5} & 1.1 .10^{3} & 16 & 1.3 .10^{1} & 00 & \text { Abs } & \text { S } \\ \text { L2 } & 5.8 .10^{6} & 3.3 .10^{3} & 13 & 1.4 .10^{1} & 00 & \text { Abs } & \text { NS } \\ \text { L3 } & 3.10^{5} & 2.10^{2} & 11 & 2.7 .10^{1} & 00 & \text { Abs } & \text { S }\end{array}$




\section{Il Macrothink}

Journal of Food Studies

ISSN 2166-1073 2020, Vol. 9, No. 1

$\begin{array}{llllllll}\text { L4 } & 8.2 .10^{5} & 5.10^{2} & 35 & 3.7 .10^{3} & 00 & \text { Abs } & \text { NS } \\ \text { L5 } & 1.3 .10^{6} & 3.6 .10^{3} & 11 & 1.3 .10^{1} & 00 & \text { Abs } & \text { NS }\end{array}$

Site $\mathrm{E}$

\begin{tabular}{llllllll} 
F1 & $2.9 .10^{6}$ & $3.9 .10^{2}$ & 16 & $4.7 .10^{2}$ & 00 & Abs & NS \\
F2 & $3.3 .10^{6}$ & $2.3 .10^{2}$ & 19 & $4.1 .10^{1}$ & 00 & Abs & NS \\
F3 & $5.10^{5}$ & $4.1 .10^{3}$ & 33 & $2.8 .10^{1}$ & 00 & Abs & NS \\
F4 & $1.2 .10^{6}$ & $1.23 .10^{4}$ & 10 & $10^{1}$ & 00 & Abs & NS \\
F5 & $1.2 .10^{5}$ & $5.4 .10^{2}$ & 18 & $3.4 .10^{1}$ & 00 & Abs & S \\
\hline
\end{tabular}

S: Satisfactory A: Acceptable NS: Unsatisfactory Abs: Absence

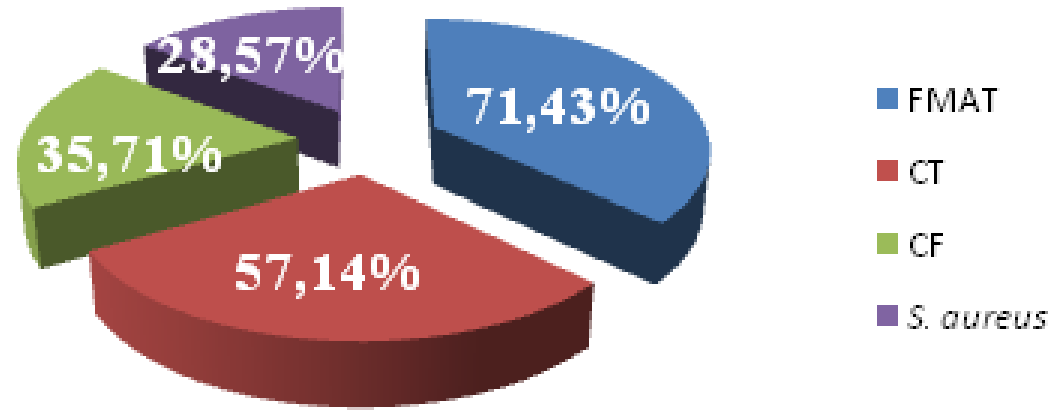

Figure 2. Proportions of non-compliance of samples by microbiological parameter

Bacteriological non-compliance of with most samples (56\%) corroborates the survey results. Only outlet B has three sellers. This large workforce indicates good organization of work, which could help reduce the contamination of minced meat in this point of sale (only $20 \%$ of non-compliant samples).

The concentration of total flora beyond the limits defined for cooked minced meat can be explained by a lack of hygiene of the preparation processes or a state of putrefaction or by the preservation of the food product at a lower temperature at $65^{\circ} \mathrm{C}$ (Ghafir et al., 2008). The presence of total coliforms ( $14.29 \%$ of samples) indicates non-compliance with good hygienic practices, and that of fecal coliforms $(21.43 \%$ of samples), a fecal contamination a human or animal origin. Unusually high concentration of coliforms in cooked minced meat may be explained by ineffective heat treatment or subsequent treatment contamination because coliforms are heat-sensitive.

The presence of Staphylococci in $7.14 \%$ of samples can be attributed to poor handling and hygiene practices. Since these bacteria are commensal to the skin and mucous membranes of humans, vendors can smear cooked ground meat with dirty hands, clothes or sneezing (Kotzekidou, 2013). In addition, some Staphylococci produce a heat-stable enterotoxin that may persist after heating or cooking minced meat. Finally, the absence of Salmonella in all cooked minced meat samples may be the consequence of the thermal effect of cooking. Gledel $\&$ Corbion (1983) reported that relatively mild heat treatments $\left(65^{\circ} \mathrm{C} / 15 \mathrm{~min}\right)$ are sufficient to kill Salmonella in contaminated food; their presence in food is therefore rare and accidental. 


\section{MInstitute ${ }^{\text {Macrothink }}$}

Dione (2000) and Ranaivoarimanana (2006), also reported a complete absence of Salmonella in ready-to-eat food samples sold in the informal sector, including cooked salads and Kobaravina. However, the total absence of salmonella in the samples should be taken with caution. In fact, Salmonella detection by the classical method may be falsely negative, depending on the nature of the isolation medium and the possible presence of competing microorganisms such as coliforms (Catsaras \& Grebot, 1984; Ilboudo et al., 2010).

\subsection{Identification of Isolated Enterobacteriaceae}

Preliminary characterization of 20 isolates of cooked ground meat revealed that $85 \%$ are potentially enterobacteriaceae. Indeed, 17 isolates are rods, mobile, Gram positive, catalase positive and non-sporogenic. The use of the biochemical gallery confirmed their belonging to this family at the species level and, Escherichia coli (35.30\%) was the most abundant species (Table 3).

Table 3. Results of biochemical identification

\begin{tabular}{|c|c|c|c|c|c|c|c|c|c|c|c|}
\hline Strains & $\underline{E}$ & อิ & $\stackrel{\mathscr{N}}{I}$ & 主 & $\underset{\triangleleft}{\longleftarrow}$ & อ & 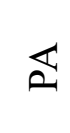 & 占 & $\underline{\Xi}$ & শ্̀ & Identification \\
\hline $\begin{array}{l}\mathrm{S}_{3}, \mathrm{~S}_{5}, \mathrm{~S}_{6}, \mathrm{~S}_{8} \\
\mathrm{~S}_{18}, \mathrm{~S}_{19}\end{array}$ & + & + & - & + & + & - & - & - & - & - & Escherichia coli $(35.30 \%)$ \\
\hline $\mathrm{S}_{11}, \mathrm{~S}_{15}$ & - & - & + & + & - & - & + & + & - & - & Proteus vulgaris $(11.76 \%)$ \\
\hline $\mathrm{S}_{16}, \mathrm{~S}_{20}$ & + & - & - & + & + & + & - & + & + & - & Klebsiella oxytoca $(11.76 \%)$ \\
\hline $\mathrm{S}_{1}, \mathrm{~S}_{7}, \mathrm{~S}_{9}, \mathrm{~S}_{13}$ & - & + & + & - & - & + & - & + & + & - & Citrobacter spp. $(23.53 \%)$ \\
\hline $\mathrm{S}_{12}, \mathrm{~S}_{14}, \mathrm{~S}_{17}$ & + & + & - & - & + & - & - & + & + & - & Enterobacter cloacae (17.65\%) \\
\hline
\end{tabular}

LDC: Decarboxylation of lysine, OX: Oxidase test, IND: Indole test

UR: Hydrolysis of urea, ODC: Decarboxylation of ornithine, CIT: Use of citrate

$\mathrm{H}_{2} \mathrm{~S}$ : Production of hydrogen sulfide, LAC: Fermentation of lactose

DUL: Fermentation of dulcitol, PA: Desamination of phenylalanine

Enterobacteria include several genera and pathogenic species, their presence in cooked meats indicates a lack of hygiene (Gueye, 2007, Ghafir et al., 2008). Among the enterobacteriaceae isolated from cooked minced meat, Escherichia coli was the predominant species. According to Lachhab (2013) and Edberg et al. (2000), the presence of Escherichia coli in a food is an indication of the presence of enteropathogenic microorganisms, which represents it a risk to the health of consumers. Several studies have reported the presence of enterobacteria in ready-to-eat meat products (Abisa, 2004; Hamiroune et al., 2017).

\subsection{Antibiotic Resistance Testing}

The proportions of the sensitive and resistant strains were respectively $57.35 \%$ and $42.65 \%$.

Intermediate responses were considered to be resistant (Table 4). The isolates showed varied resistance profiles to the different antibiotics tested and a large number of strains $(48.28 \%)$ resisted the action of cefalexin (Figure 3). In contrast, nitrofurantoin expressed good activity 


\section{Macrothink}

on enterobacterial strains, because no resistance was observed.

Table 4. Inhibition zone ( $\mathrm{mm})$ of antibiotics against enterobacterial strains

\begin{tabular}{|c|c|c|c|c|c|}
\hline Species & Strains & $\mathrm{CRO}$ & NOR & FT & $\mathrm{CN}$ \\
\hline \multirow[t]{6}{*}{ Escherichia coli } & $\mathrm{S}_{3}$ & $\mathrm{~S}$ & $\mathrm{~S}$ & $\mathrm{~S}$ & $\mathrm{~S}$ \\
\hline & $\mathrm{S}_{5}$ & $\mathrm{R}$ & $\mathrm{R}$ & $\mathrm{S}$ & $\mathrm{S}$ \\
\hline & $\mathrm{S}_{6}$ & $\mathrm{~S}$ & $\mathrm{~S}$ & $\mathrm{~S}$ & $\mathrm{~S}$ \\
\hline & $\mathrm{S}_{8}$ & $\mathrm{R}$ & $\mathrm{R}$ & $\mathrm{S}$ & $\mathrm{S}$ \\
\hline & $\mathrm{S}_{18}$ & $\mathrm{R}$ & $\mathrm{S}$ & $\mathrm{S}$ & $\mathrm{R}$ \\
\hline & $\mathrm{S}_{19}$ & $\mathrm{R}$ & $\mathrm{R}$ & $\mathrm{S}$ & $\mathrm{R}$ \\
\hline \multirow{2}{*}{ Proteus vulgaris } & $\mathrm{S}_{11}$ & $\mathrm{R}$ & $\mathrm{R}$ & $\mathrm{S}$ & $\mathrm{S}$ \\
\hline & $\mathrm{S}_{15}$ & $\mathrm{R}$ & $\mathrm{S}$ & $\mathrm{S}$ & $\mathrm{S}$ \\
\hline \multirow[t]{2}{*}{ Klebsiella oxytoca } & $\mathrm{S}_{16}$ & $\mathrm{R}$ & $\mathrm{R}$ & $\mathrm{S}$ & $\mathrm{R}$ \\
\hline & $\mathrm{S}_{20}$ & $\mathrm{R}$ & $\mathrm{R}$ & $\mathrm{S}$ & $\mathrm{R}$ \\
\hline \multirow[t]{4}{*}{ Citrobacter spp } & $\mathrm{S}_{1}$ & $\mathrm{R}$ & $\mathrm{R}$ & $\mathrm{S}$ & $\mathrm{R}$ \\
\hline & $\mathrm{S}_{7}$ & $\mathrm{R}$ & $\mathrm{R}$ & $\mathrm{S}$ & $\mathrm{S}$ \\
\hline & $\mathrm{S}_{9}$ & $\mathrm{R}$ & $\mathrm{R}$ & $\mathrm{S}$ & $\mathrm{S}$ \\
\hline & $\mathrm{S}_{13}$ & $\mathrm{R}$ & $\mathrm{S}$ & $\mathrm{S}$ & $\mathrm{S}$ \\
\hline \multirow[t]{3}{*}{ Enterobacter cloacae } & $\mathrm{S}_{12}$ & $\mathrm{R}$ & $\mathrm{R}$ & $\mathrm{S}$ & $\mathrm{S}$ \\
\hline & $\mathrm{S}_{14}$ & $\mathrm{~S}$ & $\mathrm{~S}$ & $\mathrm{~S}$ & $\mathrm{~S}$ \\
\hline & $\mathrm{S}_{17}$ & $\mathrm{R}$ & $\mathrm{S}$ & $\mathrm{S}$ & $\mathrm{S}$ \\
\hline
\end{tabular}

CRO: Ceftriaxone, NOR: Norfloxacin, CN: Cefalexin, FT: Nitrofurantoin 


\section{Macrothink}
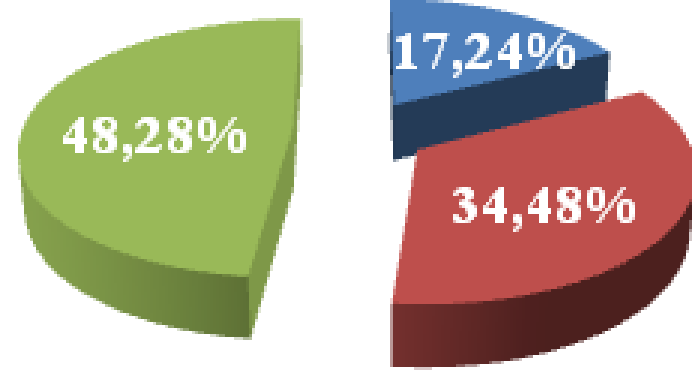

Cefalexin

- Norfloxacin

Ceftriaxone

Figure 3. Proportions of resistant strains by antibiotic

The resistance to antimicrobial agents by bacterial pathogens is a major hindrance to successful therapy and some bacterial strains have been reported to be resistant to most available antimicrobial treatments (Oladipo \& Adejumobi, 2010). In this study, enterobacterial strains $(42.65 \%)$ were resistant to cefalexin, ceftriaxone and norfloxacin. The first two antibiotics belong to the $\beta$-lactam family. Robin et al., (2012) and Okalla et al., (2015) reported that most enterobacterial species naturally harbor and have resistance to $\beta$-lactams, as they produce $\beta$-lactamases. These enzymes hydrolyze $\beta$-lactams by inactivating the antibiotic in question (Ambler, 1991). The resistance of enterobacteria to fluoroquinolones, such as norfloxacin, is mainly due to a lack of affinity of the target and more rarely to efflux phenomena (Merensa \& Servonneta, 2010). Enterobacteriaceae have an obvious ability to acquire and exchange genes that carry resistance factors and the intestinal flora provides an extraordinary opportunity for the flow of genetic information between bacteria (Van Immerseel et al., 2004). This frequent acquisition of antibiotic resistance mechanisms explains that Enterobacteriaceae are the bacteria most often implicated in human infectious pathology.

\section{Conclusion}

Ground meat sandwiches sold in the informal sector in Brazzaville can be a source of enteropathogens, which could expose consumers to food poisoning. The reduction of this health risk can be done through information sessions for sellers on health education, promotion of personal hygiene and food hygiene.

\section{Acknowledgment}

We thank the members of the Multidisciplinary Food and Nutrition Research Team (EPRAN) and the National Research Institute for the Natural Sciences (IRSEN) for the technical support provided to carry out this work.

\section{References}

Ambler, R. P., Coulson, A. F. W., Frére, J. M., Ghuysen, J. M., Joris, B., Forsman, M., Levesque. R. C., Tiraby, A., \& Waley, S. G. (1991). A standard numbering scheme for the class A $\beta$-lactamases. Biochem. J, 276, 69-270. https://doi.org/10.1042/bj2760269

Anin, L. A., Yapi, A. Y., Yapo, T. M., Yiwo, Y. M-A., Lêniféré, S. C., \& Kouakou, K. A. (2016). Evaluation microbiologique et origines de la contamination des produits de $4{ }^{\text {ème }}$ gamme vendus sur les marchés d'Abidjan, Côte d'Ivoire. European Scientific Journal, 12, 1857-7881.

Badibanga, N. (2008). Innocuité bactériologique des saucissons vendus sur la voie publique à 
Kisangani, mémoire inédit, Faculté des Sciences UNIKIS, 25p.

Barro, N., Ouattara, C. A. T., Nikiema, A. P., Ouattara, A. S., \& Traore, S. A. (2002). Microbial Quality Assessment of Some Street Food Widely Consumed in Ouagadougou, Burkina Faso. Health, 12(4), 369-374.

Barro, N., Bello, A. R., Itsiembou, Y., Savadogo, A., \& Ouattara, C. A. T. (2007). Street-Vended Foods Improvement: Contamination Mechanisms and Application of Food Safety Objective Strategy: Critical Review. Pakistan Journal of Nutrition, 6(1), 01-10.

Bauer, A. W., Kirby, W. M. M, Sherris, J. C., \& Turk, M. (1996). Antibiotic susceptibility testing by a standardized single disk method. American Journal of Clinical Pathology, 45(4), 493-496. https://doi.org/10.1093/ajcp/45.4_ts.493

Catsaras, M., \& Grebot, D. (1984). Multiplication of salmonella in minced meat. Bull. Acad. Vet. France, 57, 501-502. https://doi.org/10.4267/2042/65006

Christison, C. A, Lindsay, D., \& Holy, A. V. (2008). Microbiological survey of ready-to-eat foods and associated preparation surfaces in retail delicatessens, Johannesburg, South Africa. Food Control, 19(7), 727-733. https://doi.10.1016/j.foodcont.2007.07.004

Clinical and Laboratory Standards Institute, CLSI document M100-S23. (2013). Performance standards for antimicrobial susceptibility testing, 20th informational supplement, Wayne, Pennsylvania 19087 USA.

Cohen, N., \& Karib, H. (2006). Risque hygiénique lié à la présence d'E. coli dans les viandes et produits carnés consommés en restauration collective. L'aliment Vie, 65, 314-27.

Dione, A. (2000). Contribution to the study of the bacteriological quality of some foodstuffs of animal origin sold on the Dakar market. Th. Méd. Vet. EISM, Dakar.

Edberg S., Rice., \& Rjkarlinet Allen. (2000). Escherichia coli: the best biological drinking water indicator for public health protection. Symp Ser Soc Appl Microbiol, 29, 106S-116S. https://doi.org/10.1111/j.1365-2672.2000.tb05338.x

El Allaoui, A., Filali, F., Ameur, N., \& Oumokhtar, B. (2012). Qualité hygiénique des saucisses fabriquées traditionnellement dans la ville de Meknès. Science lib éditions Mersenne, $\mathrm{n}^{\circ} 120707$.

Ghafir, Y., China, B., Dierick, K., De Zutter, L., \& Daube, G., (2008). Hygiene indicator microorganisms for selected pathogens on beef, pork, and poultry meats in Belgium. J. Food Prot, 71(1), 35-45. https://doi.org/10.4315/0362-028x-71.1.35

Gueye, O. (2007). Utilisation des méthodes biométriques dans 1"identification de quelques bacilles a Gram négatif. Thèse doctorat. Université cheikh Anta Diop de Dakar. 120p.

Hamiroune, M., Saidani, K., Naceur, R., Belarbi, H.S., Foughalia, A., \& Berber, A. (2017). Microbiological quality of Merguez in some retailing meat shops in the region of M'Sila (Algeria). Afr. J. Microbiol. Res, 11(6), 211-217. https://doi.org/10.5897/AJMR2016.8406

Ilboudo, A. J., Savadogo, A., Barro, N., Ouedraogo, M., \& Traore, A. S. (2009). Qualité hygiénique de la viande utilisée en restauration collective dans trois restaurants universitaires de Ouagadougou (Burkina Faso). Cahiers Santé, 19(4), 195-199. https://doi.org/10.1684/ san.2009.0146

Joffin, C., \& Joffin, J. N. (2003). Microbiologie alimentaire. Biologie et Technique, Aquitaine, 


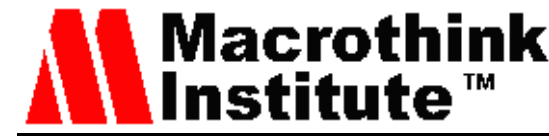

$212 \mathrm{p}$.

Kotzekidou, P. (2013). Microbiological examination of ready-to-eat foods and ready-to-bake frozen pastries from university canteens. Food Microbiol, 34(2), 337-43. https://doi.org/ 10.1016/j.fm.2013.01.005.

Lachhab, L. (2013). Evaluation de la qualité hygiénique des salades prêtes à consommer dans la ville de Fès. Projet de fin d'études. Université Sidi Mohamed Ben Abdellah, Alger.

Mensah, P., Yeboah-Manu, D., Owusu-Darko, K., \& Ablordey, A. (2002). Street foods in Accra, Ghana: how safe are they? Bulletin of the World Health Organization, 80(7), 546-554. https://doi.org/ 10.1590/S0042-96862002000700006

Mérens, A., \& Servonnet, A. (2010). Mécanismes et épidémiologie de la résistance aux fluoroquinolones en 2010. Revue Francophone des Laboratoires, 422, 33-41. https://doi.org/ 10.1016/S1773-035X (10)70508-6

Ogunsola, O., \& Omojola, A. (2008). Qualitative evaluation of Kilishi prepared from beef and pork, Afr.J.Biotechnol, 7(11), 1753-1758, https://doi.org/10.5897/AJB08.354

Okalla E. C., Tsiazok, M. D., Mefo'o, J. P. N., Ngaba, G. P., Beyiha, G., \& Adiogo. (2015). Evolution of antibiotic resistance in enterobacteriaceae isolated at the Douala General Hospital from 2005 to 2012, Pan Afr Med J, 20, 227. https://doi.org/10.11604/pamj.2015. 20.227.4770

Oladipo, I. C., \& Adejumobi, O D. (2010). Incidence of antibiotic resistance in some bacterial pathogens from street vended food in Ogbomoso, Nigeria. Pakistan Journal of Nutrition, 9(11), 1061-1068.https://doi.org/10.3923/pjn.2010.1061.1068

Phillips, D., Summer, J., Alexander, J., \& Duttonk, K. (2001). Microbiological quality of Australian beef. Journal of Food Protect, 64(5), 692-696. https://doi.org/0362-028X-64.5.692 Ranaivoarimanana, R. (2006). Contribution to the study of street food in the city of Talatan'nyvolonondry (Madagascar): case of Koba Ravina (85p). DEA Memory, Faculty of Sciences, Université d'Antananarivo, Antananarivo.

Robin, F., Gibold, L., \& Bonnet, R. (2012). Intrinsic or acquired resistant to $\beta$-lactams in Enterobacteriaceae: How to identify them in clinical practice, Revue Francophone des Laboratoires, V2012 (445), 47-58. https://doi.org/10.1016/S1773-035X(12)71676-3

Van Immerseel, F., Fievez, V., De Buck, J., Pasmans, F., Martel, A., Hasbrouck, F., \& Ducatelle, R. (2004). Microencapsulated short-chain fatty acids in feed modify colonization and invasion early after infection with Salmonella enteritidis in young chickens. Poult. Sci., 83, 69-74. https://doi.org/ 10.1093/ps/83.1.69

\section{Copyright Disclaimer}

Copyright for this article is retained by the author(s), with first publication rights granted to the journal.

This is an open-access article distributed under the terms and conditions of the Creative Commons Attribution license (http://creativecommons.org/licenses/by/4.0/). 